Int. J. Dev. Biol. 52: 811-821 (2008)

doi: $10.1387 / \mathrm{ijdb} .082655 \mathrm{am}$

\title{
The enigmatic role of the ankyrin repeat domain 1 gene in heart development and disease
}

\author{
ALEXANDER T. MIKHAILOV* and MARIO TORRADO \\ Developmental Biology Group, Institute of Health Sciences, University of La Coruña, La Coruña, Spain
}

\begin{abstract}
It has been proposed that the ankyrin repeat domain 1 (ANKRD1) factor (also known as CARP) plays a critical role in transcriptional regulation, myofibrillar assembly and stretch sensing during heart development and cardiac insults. ANKRD1/CARP has also been reported to negatively regulate cardiac gene expression in cell-based promoter-reporter assays. Consequently, rapid up-regulation of the ankrd1 gene in myocardium in response to developmental stimuli or pathological insults has tended to be interpreted in the context of the inhibitory effects of ANKRD1 on cardiomyocyte gene expression. Surprisingly, a total ankrd1 knockout resulted in a complete lack of phenotype, suggesting that ANKRD1/CARP is not crucial for regulation of cardiac gene expression in vivo. In this essay, we summarize (1) the accumulated evidence for the apparent multifunctional properties of this enigmatic protein, (2) the distinct chamber-dependent regulation of ankrd1 expression patterns in the heart, both during development and cardiac injury, and (3) ANKRD1 involvement in networks regulating adaptation of the myocardium to stress. Whenever feasible, we present the results obtained in patients together with those obtained in the relevant animal and cellular models. A close examination of the findings still fails to define ANKRD1 as a negative regulator of cardiac gene expression in vivo, but rather indicates that its augmented expression can represent an adaptive response of the myocardium to stress both during development and various heart insults.
\end{abstract}

KEY WORDS: CARP, heart development, heart failure, stress-responsive regulator, expression patterns

\section{Introduction}

Throughout development, morphogenetic processes drive the formation of the highly specialized four-chambered mammalian heart. Once cardiac development is completed, postnatal functional maturation of the heart takes over extending the use of developmental signaling factors and pathways to adulthood. As a result, many of the cardiac-restricted factors originally characterized within a purely developmental context are now becoming significant in clinically relevant cardiac research (Hoshijima and Chien, 2002; Akazawa and Komuro, 2003b; Franco and Campione, 2003; Olson and Schneider, 2003; Olson, 2004; Olson, 2006).

The gene for cardiac ankyrin repeat domain 1 (ANKRD1) transcriptional co-factor (also known as CARP), through linking the process of heart development to heart disease, stimulated much interest in studying its potential functions in cardiac muscle tissue. In the fetal heart, ANKRD1/CARP has been implicated in negative transcriptional regulation of cardiac gene expression (Jeyaseelan etal., 1997; Zou etal., 1997). Later, ANKRD1/CARP expression has been found to be rapidly induced in cardiomyocytes in response to hypertrophy stimuli, as well as, at heart failure (HF), suggesting an involvement of ankrd1activities in physiological and pathological remodeling of ventricular myocardium (Aihara et al., 2000; Zolk et al., 2002; Nagueh et al., 2004). Recently, ankrd1 has been identified as a candidate gene that can play a role in congenital heart disease (Cinquetti et al., 2008).

The available information on the molecular functions of ankrd1 suggests that the gene plays a critical role in transcriptional

\footnotetext{
Abbreviations used in this paper: ANKRD1, ankyrin repeat domain 1; CARP, cardiac ankyrin repeat protein; AF, atrial fibrillation; HF, heart failure; MARPs, muscle ankyrin repeat proteins; CASQ2, cardiac calsequestrin; MuRF1/MuRF2, muscle-specific RING finger 1 and 2 ubiquitin ligases; SRF, serum response factor; $\mathrm{LV} / \mathrm{RV}$, left/right ventricular; MLC2v, myosin light chain 2 ventricular; ANF, atrial natriuretic factor; DCM, dilated cardiomyopathy; Dox, Doxorubicin; YB-1, Y box binding protein 1; TNNC, cardiac troponin C; MLP, muscle LIM-only protein; FHF/SHF, first/second heart field; MVECs, microvascular endothelial cells.
}

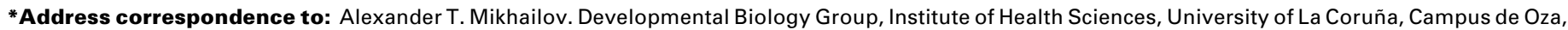
Building “El Fortín”, As Xubias s/n, 15006 La Coruña, Spain. Fax: +34-981-138714. e-mail: margot@udc.es
} 
regulation, myofibrillar assembly, stretch sensing, and in communication between the sarcoplasm and the nucleus (Granzier and Labeit, 2004; Miller et al., 2004). However, one decade after the discovery of ANKRD1/CARP as a fetal cardiac-restricted transcriptional co-factor (Zou et al., 1997), the in vivo functions of ANKRD1/CARP remain elusive, largely because neither heartspecific deletion/down-regulation of the gene nor cardio-restricted ankrd1 transgenesis have been reported yet. Of note, a total ankrd1 knockout resulted in a complete lack of phenotype (Barash et al., 2007). Nevertheless, rapid in vivo up-regulation of ankrd1 in fetal, neonatal and adult heart in response to stress underscores its importance as a regulator of physiological and pathological processes that is only beginning to be appreciated (Baudet, 2003; Granzier and Labeit, 2004; Miller et al., 2004; Torrado et al., 2005b; Samaras et al., 2006; Samaras et al., 2007; Cinquetti et al., 2008).

In this paper, we revise the properties and regulation of ANKRD1/CARP with particular reference to cardiac muscle development and disease by discussing several important issues related to: (1) the molecular properties of ANKRD1/CARP as a versatile factor that may exert pleiotropic functions in the cardiomyocyte at multiple levels, (2) the unique expression features of ankrd1 that may be linked to regional specification of the four-chambered heart, (3) the modulations of ankrd1 regional expression at various heart insults, and (4) the ANKRD1/CARP function as a negative regulator of cardiac gene expression. A close examination of the findings fails to define ANKRD1/CARP as a negative regulator of cardiac gene expression in vivo, but rather indicates its involvement in an adaptive response of the heart to biomechanical alterations relevant to both heart development and heart disease. ${ }^{1}$

\section{ANKRD1 is a putatively multifunctional factor: the inte- gration of sequence-based predictions and experimen- tal data}

ANKRD1/CARP is a founding member of a family of conserved muscle ankyrin repeat proteins (MARPs; Ikeda et al., 2003; Miller et al., 2003). Sequence analysis and in silico sequence-based predictions revealed the following features in mammalian ANKRD1s (Fig. 1): four tandem ankyrin repeats, the coiled-coil domain, nuclear localization signal motif, potential PEST protein degradation sequence, and putative phosphorylation and glycosylation sites (Chu et al., 1995; Jeyaseelan et al., 1997; Zou et al., 1997; Aihara et al., 1999; Miller et al., 2003; Torrado et al., 2004; Witt et al., 2005).

Ankyrin repeats have been found in many proteins spanning a wide range of interesting functions such as transcriptional regulation, cell-cycle control, developmental cell-fate decisions, cytoskeleton integrity, cellular mechanosensory, and endocytosis (Mosavi et al., 2004). This can be attributed, at least in part, to the capacity of ankyrin repeat-containing proteins to interact with other polypeptides. As detected by yeast two-hybrid screening, the N2A region of the sarcomeric no-contractile protein, titin, interacts with ANKRD1/CARP. The N2A titin fragment bound to two distinct ANKRD1/CARP sites, one of which encompass the sequence containing ankyrin repeat 2 (Miller et al., 2003) (see Fig. 1). Using pull-downs, co-immunoprecititation and in vitrobinding assays, we identified a strong and selective interaction of ANKRD1/ CARP with cardiac calsequestrin-2 (CASQ2) and 37- and 42-kDa fragments of titin. Mapping of the peptides involved in the ANKRD1CASQ2 interaction revealed that three of the five binding sequences for CASQ2 are located in ankyrin repeat 2, 3, and 4 of ANKRD1/CARP (Torrado et al., 2005a) ${ }^{2}$.

We detected the coiled-coil domain in the $\mathrm{N}$-terminal part of ANKRD1/CARP and demonstrated that the domain can contribute to ANKRD1/CARP self-dimerization (Torrado et al., 2004). Later this data was confirmed and extended by other approaches (Witt et al., 2005; Torrado et al., 2008). The ANKRD1-ANKRD1 self-interaction represents a weak interaction (Witt et al., 2005; Mikhailov and Torrado, 2006) thus reducing the probability that in cardiomyocytes ANKRD1/CARP oligomerization via the coiledcoil domain could be sufficient to promote a stable multivalent interaction of ANKRD1/CARP dimers with two or more molecules, permitting those molecules to function in a coordinated way.

In addition to ANKRD1/CARP interactions with titin and CASQ2 which are mediated, at least partially, by its binding sites localized within the ankyrin repeats and coiled-coil domain (see Fig. 1), several other partners of ANKRD1/CARP have been identified. In particular, using various combinations of two-hybrid, pull-down and co-immunoprecipitation assays, it has been demonstrated that ANKRD1/CARP can interact with Y-box transcription factor 1 (YB-1; Zou etal., 1997), as well as, sarcomeric protein, myopalladin (Bang et al., 2001), desmin (Witt etal., 2005), and muscle-specific RING finger proteins (MuRF1/MuRF2; Witt et al., 2008). It is

\section{TABLE 1}

\section{PREDICTION SCORES FOR CYTOPLASMIC AND NUCLEAR LOCALIZATIONS OF MAMMALIAN ANKRD1/CARP}

\begin{tabular}{|c|c|c|c|c|}
\hline \multirow[t]{2}{*}{ Acc. No. } & \multirow[t]{2}{*}{ Species } & \multirow{2}{*}{$\begin{array}{l}\text { Subcellular } \\
\text { localization }\end{array}$} & \multicolumn{2}{|c|}{ Reliability } \\
\hline & & & PSORT II & CELLO \\
\hline \multirow[t]{2}{*}{ NP_055206 } & human & Cytoplasmic & $47.8 \%$ & $69.80 \%$ \\
\hline & & Nuclear & $26.1 \%$ & $19.50 \%$ \\
\hline \multirow[t]{2}{*}{ NP_999087 } & pig & Cytoplasmic & $65.2 \%$ & $68.70 \%$ \\
\hline & & Nuclear & $17.4 \%$ & $20.28 \%$ \\
\hline \multirow[t]{2}{*}{ NP_001029550 } & bovine & Cytoplasmic & $56.5 \%$ & $69.18 \%$ \\
\hline & & Nuclear & $26.1 \%$ & $20.58 \%$ \\
\hline \multirow[t]{2}{*}{ NP_001075523 } & rabbit & Cytoplasmic & $47.8 \%$ & $62.80 \%$ \\
\hline & & Nuclear & $26.1 \%$ & $23.98 \%$ \\
\hline \multirow[t]{2}{*}{ NP_037352 } & rat & Cytoplasmic & $52.2 \%$ & $59.96 \%$ \\
\hline & & Nuclear & $21.7 \%$ & $23.14 \%$ \\
\hline \multirow[t]{2}{*}{ NP_038496 } & mouse & Cytoplasmic & $52.2 \%$ & $64.44 \%$ \\
\hline & & Nuclear & $21.7 \%$ & $20.62 \%$ \\
\hline
\end{tabular}

CELLO scores have been converted to the percentage

Note 1: Ankyrin repeat domain 1 (cardiac muscle) - symbol approved by the HUGO Gene Nomenclature Committee (NGNC database). Aliases: C-193, CARP, MARP, MCARP. Discussion on ANKRD1 as a surrogate marker of ventricular hypertrophy (Kuo et al., 1999; Aihara et al., 2000), as well as, a cardiac-restricted target for Doxorubicin (Jeyaseelan et al., 1997; Chen et al., 2007) is outside the purposes and scope of the present article.

Note 2: ANKRD1/CARP and CASQ2 are highly detected and co-distributed in ventricular Purkinje cells, and ANKRD1/CARP selectively and specifically interacts with endogenous CASO2 in LV-derived extracts (Torrado et al., 2005a). 


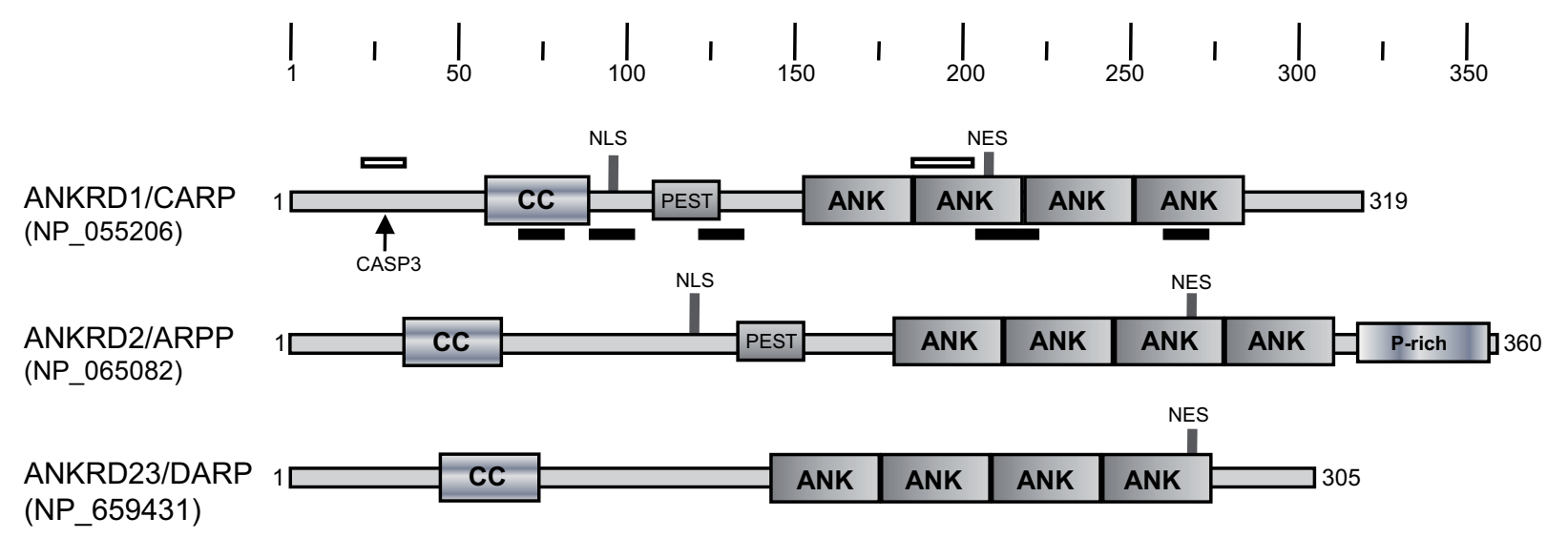

Fig. 1. Muscle ankyrin repeat protein family. Human cardiac ankyrin repeat protein (ANKRD1/CARP), ankyrin repeat protein with a proline-rich (Prich) region (ANKRD2/ARPP) and diabetes related ankyrin repeat protein (ANKRD23/DARP) sequences are shown. Coiled-coil (CC) and ankyrin repeat (ANK) domains, nuclear localization (NLS) and nuclear export (NES) signals, and PEST-like motifs were mapped using the COILS, ScanProsite, PredictNLS, NetNES and PESTfind algorithm, respectively. CASP3, caspase-3 cleavage site. On human ANKRD1/CARP, two titin-binding (horizontal white rectangles) and five CASQ2-binding (horizontal black rectangles) sequences are shown.

interesting to note that only full-length ANKRD1/CARP (but not mutated versions of the protein) effectively binds with myopalladin (Bang et al., 2001). The list of potential ANKRD1/CARP physical partners is not limited to the molecular interactions discussed, because several as of yet uncharacterized myocardial proteins were found to be capable of interacting with ANKRD1/CARP (Torrado et al., 2005a; Witt et al., 2005). The diverse range of ANKRD1/CARP binding partners, including transcription factors (YB-1), myofibrillar (titin, myopalladin), intermediate filament (desmin), calcium-handling (CASQ2), and ubiquitin ligase (MuRF1/ MuRF2) proteins suggests both the pleiotropic and integrative functions of ANKRD1/CARP in cardiomyocytes. Consequently, it is crucial to our further understanding of the functions of ANKRD1/ CARP to elucidate these interactions in vivo.

The primary structure of ANKRD1/CARP also contains several features that indicate the possible dual nuclear and cytoplasmic functions of the protein (i.e., the nuclear localization and nuclear export signal; see Fig. 1). Moreover, the results of our computer analyses of ANKRD1/CARP sequences by PSORT II (Nakai and Horton, 1999) and CELLOv2.5 (Yu etal., 2006) algorithms yielded highly confidential predictions for cytoplasmic localization of the proteins, with much lower prediction scores for their nuclear localization (Table 1).

These sequence-based predictions are well in line with both cytoplasmic and nuclear localization of immuno-decorated ANKRD1/CARP on human (Ishiguro et al., 2002; Nagueh et al., 2004) and porcine (Torrado et al., 2005a; Torrado et al., 2006) heart sections. At the immunoelectron-microscopy level, ANKRD1/ CARP epitopes were detected in the central I-band, as well as, within the nucleolus of mouse fetal (Miller et al., 2003) and postnatal (Bang et al., 2001) cardiomyocytes. Consistent with these findings, FLAG- (Jeyaseelan et al., 1997) or GFP-tagged (Miller et al., 2003; Zolk et al., 2003) ANKRD1/CARP was localized in both the nucleus and cytoplasm of transfected neonatal rat cardiomyocytes. ANKRD1/CARP is enriched in the insoluble myofibrillar bound fraction (Torrado et al., 2005a; Hayashi et al., 2008), consistent with its strong binding to titin and myopalladin. Although additional studies are required to determine the significance of ANKRD1/CARP subcellular localization, it has been proposed (Granzier and Labeit, 2004; Miller et al., 2004) that ANKRD1/CARP can function: (1) as a component of a titinassociated stretch-sensing complex in the myofibril and (2) as a co-factor of YB-1-regulated transcription in the nucleus.

Summarizing, the integration of sequence-based predictions and experimental data points to potentially pleiotropic functions of the cardiac ANKRD1/CARP brought about via protein-protein interactions and dual nuclear-cytoplasmic localization.

\section{ANKRD1 expression patterns in fetal, neonatal and mature heart: atrial versus ventricular and left versus right asymmetry}

The developmental patterns and developmental modulation of cardiac ankrd1 expression in mammals are not yet completely understood. In mice, at relatively early stages of cardiac embryogenesis (stage E8 - E10) ankrd1expression assessed by section or whole-mount in situ hybridization was found to be uniform throughout all cardiac tissue compartments (Jeyaseelan et al., 1997; Zou et al., 1997). Shortly after, intensity of ankrd1 hybridization signals started to decline in ventricular myocardium remaining strong in the atrium and outflow tract (Zou et al., 1997). In late fetal and neonatal mice, ankrd1 hybridization signal was found to be stronger in the atrial as compared to ventricular myocardium (Jeyaseelan et al., 1997). In 11-14-week-old human fetuses ANKRD1/CARP-positive myocytes (as revealed by immunocytochemistry) were uniformly distributed throughout the heart (Ishiguro et al., 2002).

Ankrd1 expression was found to be significantly and selectively reduced in the fetal heart of $N k \times 2.5$ knockouts, indicating that $N k \times 2.5$ regulates transcription of ankrd1 (Zou et al., 1997). On the other hand, the ankrd1 gene was up-regulated in the postnatal heart of transgenic mice overexpressing $N k \times 2.5$ (Takimoto et al., 2000). It has been demonstrated that $N k x 2.5$ can indirectly control ankrd1 promoter activity through a transcription factor, GATA-4, that activates the mouse ankrd1promoter through a proximal GATA-4 ciselement (Kuo et al., 1999). Recently, $N \times k 2.5$ was found to bind in vivoto the $2.5-\mathrm{kb}$ upstream regulating region of the ankrd1 gene, a region essential for ankrd1 expres- 
sion (van Loo et al., 2007). Other factors may also be involved in activating the ankrd1 promoter in cardiomyocytes (Aihara et al., 2000; Maeda et al., 2002). In this sense, serum response factor(SRF)-null neonatal cardiomyocytes exhibit an attenuation of Nkx2.5, gata-4and ankrd1 expression (Balza and Misra, 2006), and ankrd1 is presently a hypothetical SRF target (Miano et al., 2007). Deficiency in the Sp3transcription factor also results in downregulation of ankrd1 expression in ventricular (but not atrial) myocardium although $N k \times 2.5$ and gata-4 expression was not disturbed in the $S p 3^{/-}$heart. The $2.5-\mathrm{kb}$ upstream region of the ankrd1 gene contains $S p 3$ binding sites suggesting that ankrd1 can be a direct target of the Sp3 gene (van Loo et al., 2007). The authors of this work suggest that Nkx2.5 and gata-4 are required for initial induction of ankrd1 expression in developing mouse heart whereas $S p 3$ is essential to maintain the appropriate expression pattern of ankrd1 selectively in the ventricles from stage E12.5 onwards.

Concerning the developmental dynamics of ankrd1 expression in the left ventricular (LV) myocardium, Northern blot hybridization analysis in mice (Kuo et al., 1999) and cDNA microarray profiling in rats (Sehl et al., 2000) revealed higher levels of the ankrd1 transcript in fetal as compared to those in adult ventricular myocardium. In other work, however, total cardiac levels of the ankrd1 mRNA were found to be significantly higher in adults than those in early postnatal mouse heart (Johnatty et al., 2000). A gradual increase in ventricular ankrd1 expression from late-fetus, neonate, to adult stages was demonstrated in rats (Aihara et al., 2000) and pigs (Torrado et al., 2004; Torrado et al., 2005b), suggesting an association of ankrd1 expression with physiological hypertrophic remodeling of LV myocardium. In this sense, maternal undernutrition in sheep in early- to mid-gestation led to fetal ventricular hypertrophy which in turn resulted in significant ankrd1 up-regulation in the LV (Han et al., 2004).

Collectively, these results indicated that: (1) ankrd1 expression is not only exclusively associated with cardiac fetal devel- opment, but also represents an expression feature constitutive of the postnatal and adult ventricular myocardium, (2) embryonic expression of ankrd1 seems to become repressed in the late fetal phase, and (3) ventricular ankrd1 expression is reactivated to some extent from early neonatal stage towards the adulthood.

One of the attractive features derived from cardiac ankrd1 profiling studies is that in the fetal (Jeyaseelan et al., 1997; Zou et al., 1997) and neonatal (Gessler et al., 2002) mouse as well as, in perinatal and early postnatal piglet heart (Torrado et al., 2004), the gene is expressed at higher levels in atria as compared to ventricles (i.e., atrial versus ventricular expression). Another, but not less intriguing and provocative, observation is that in newborn and early postnatal piglets pan-cardiac ankrd1 expression is characterized by distinct left- and rightside patterns resulting in an overall left versus right asymmetry of ankrd1 transcript and protein in both atrial and ventricular myocardium (Torrado et al., 2004; Torrado et al., 2005b; Torrado et al., 2006).

How are these specific patterns of ankrd1 transcriptional activity established? Differential expression of the gene can partly be explained by distinct 5' cis regulatory elements of the ankrd1 gene that can direct chamber-dependent gene expression, such as atrial versus ventricular and left versus right (Kuo et al., 1999). Whereas the regulatory cis-sequences responsible for chamber-dependent expression of ankrd1 have been identified, the trans-acting factors interacting with these sites are not yet precisely delineated.

As mentioned above, Nkx2.5 can interact with GATA-4 and activates, in turn, the mouse ankrd1 promoter that contains the GATA-4 binding site in its upstream regulatory region (Kuo et al., 1999). The NkX2.5transcript is distributed homogeneously throughout the fetal and adult mouse myocardium (Komuro and Izumo, 1993; Schwartz and Olson, 1999). Gata-4is also broadly expressed across atrial and ventricular regions of the developing mouse heart (Heikinheimo et al., 1994; Brewer and Pizzey,

TABLE 2

\section{ANKRD1/CARP EXPRESSION LEVELS IN DILATED CARDIOMYOPATHY AND HEART FAILURE}

\begin{tabular}{|c|c|c|c|c|}
\hline Model & Cardiac phenotype & Clinical phase & Ankrd1 expression & Reference \\
\hline \multirow[t]{2}{*}{ MLP-deficient mice } & early - VH & end-stage HF & transcript (up) & Arber et al., 1997 \\
\hline & late - DCM & end-stage HF & transcript (up) & Baumeister et al., 1997 \\
\hline \multirow[t]{2}{*}{ CASQ2-overexpressing mice } & early - VH & depressed contractility & transcript (up) & Ihara et al., 2002 \\
\hline & late - DCM & end-stage HF & transcript (up) & \\
\hline Gs-alpha-overexpressing mice & late - DCM & advanced HF & transcript (up) & Gaussin et al., 2003 \\
\hline \multirow[t]{2}{*}{ IR and IGF-1R double-knockout mice } & $\mathrm{DCM}$ & early-stage HF & transcript (no change) & Laustsen et al., 2007 \\
\hline & & end-stage HF & transcript (up) & \\
\hline Ventricular pacing in dogs & DCM-like & end-stage HF & transcript (up) & Zolk et al., 2002 \\
\hline F vs NF human hearts & IDCM & end-stage HF & protein (up) & Nagueh et al., 2004 \\
\hline \multirow[t]{2}{*}{ F vs NF human hearts } & IDMC & end-stage HF & transcript (up) & Zolk et al., 2002 \\
\hline & & & protein (up) & \\
\hline
\end{tabular}

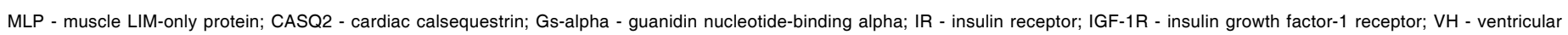
hypertrophy; DCM - dilated cardiomyopathy; IDCM - idiopatic DCM; F - failing heart; NF - non-failing heart. 
A
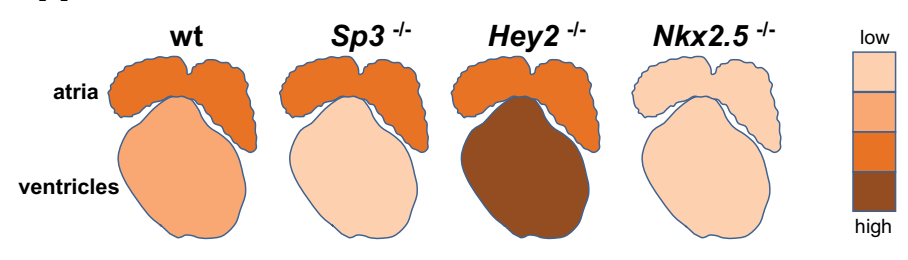

B

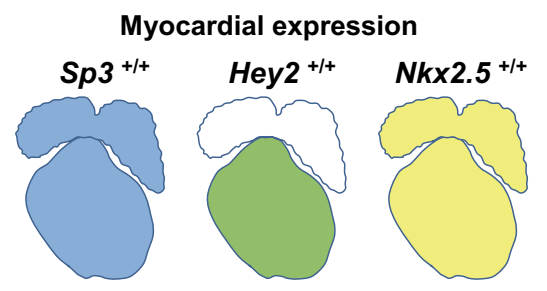

Fig. 2. Regulatory signals that may influence atrial versus ventricular expression of the ankrd1 gene in the fetal myocardium. (A) Simplified schematics of ankrd1 expression in the myocardium of Sp3-, Hey2- and Nkx2.5-defficient, and wild-type (wt) mouse embryos. Color gradient scale represents low-to-high ankrd1 expression levels. (B) Simplified schematics of expression levels of Sp3 (blue), Hey2 (green) and $\mathrm{Nk} \times 2.5$ (yellow) in the myocardium of wide-type mouse embryos are shown. Correlative expression data $(A, B)$ provides a context for a minimal model of regulation of ankrd1 expression in atrial versus ventricular myocardium. See text for further details.

2006). Thus, the results on $N k \times 2.5$ and gata- 4 expression patterns in the mouse heart do not suggest an obvious mechanism by which distinct, atrial versus ventricular, patterns of ankrd1 expression may be achieved.

During heart development basic helix-loop-helix transcription factors Hey1 and Hey2 show a clear regionally restricted expression, the first being active exclusively in the atria and the second in the ventricles (Leimeister et al., 1999) ${ }^{3}$. Hey2 can suppress cardiac gene expression through a direct inhibitory interaction with GATA-4 that interferes with DNA binding (Kathiriya et al., 2004; Xiang et al., 2006). It has been demonstrated that in vivo Hey2 limits the level of GATA-4/6-driven genes, such as ankrd1 and atrial natriuretic factor (ant), to a certain level, while loss of Hey2 activity leads to up-regulation of these genes in ventricular myocardium (Fig. 2). These effects were not associated with inhibition of gata-4/6expression in the ventricles of Hey-2-defficient embryos. In the atria of Hey2 knockouts, ankrd1, anf and gata-4 levels were unchanged, consistent with the ventricular restriction of Hey2 expression (Fischer et al., 2005). These results suggest that the ankrd1 atrial versus ventricular pattern in the fetal and neonatal heart is not exclusively driven by the distribution of positive factors, but likely by the imposition of region-specific restraints on expression. Of note, Hey-2-mediated inhibition of ankrd1 expression in the ventricular myocardium can be counterbalanced by positive ankrd1 regulators, others than $N k \times 2.5$ and gata-4 (see Fig. 2). One of such positive regulators, the transcriptional factor $S p 3$ is expressed ubiquitously in the developing mouse heart ${ }^{4}$. Nevertheless, Sp3-deficient mice display a highly reduced expression of ankrd1 only in the ventricles: ankrd1 expression is almost completely lost from the ventricular myocardium, excepting a region in the septum that coincides with the position of the future ventricular conductive system (van Loo et al., 2007).

Regulatory mechanisms resulting in left versus right asymmetric ANKRD1/CARP patterns in the newborn and early postnatal heart (Torrado et al., 2004; Torrado et al., 2005b; Torrado et al., 2006) remain to be elucidated. HAND1/eHAND and HAND2/dHAND transcription factors that have distinct, left versus right, roles in the development of ventricular myocardium (Akazawa and Komuro, 2003a) are equally expressed in both the left (LV) and right ventricle (RV) of neonatal piglets, suggesting that these factors are not involved in ankrd1 expression sidedness (Torrado et al., 2004).

Ankrd1 expression sidedness seen in the late fetal - early neonatal pig heart is actually at the end of a process of L-R axis determination and establishment. While transcription factors like $N k \times 2-5$ function in both the first (FHF) and second (SHF) heart field, others appear to be restricted to the FHF or the SHF. $T b \times 5$, the T-box family transcription factor, represents one such factor that is expressed in the FHF and, later in development, in atria and LV, but not in the RV and outflow tract. Ablation of $T b \times 5$ in mice results in a severe hypoplasia of the LV and atrial compartment, while the RV and outflow tract are not affected (Bruneau et al., 2001). Interestingly, Tbx5interacts directly with the $N k \times 2-5$ factor and, in vitro, cooperatively activates expression of the ankrd1 gene (Hiroi et al., 2001). Thus, it seems probable that the association and positive functional coupling of Tbx5and NkX2-5might lead to left predominant ankrd1 expression in the heart.

The cardiac wall contains not only working myocytes, but also impulse-conducting cells, myofibroblasts, and endothelial cells. Expression of ankrd1 in cardiac fibroblasts and endothelial cells has not been reported. Using immunohistochemical detection, we found significant ANKRD1/CARP enrichment in ventricular Purkinje cells of early postnatal piglets (Torrado et al., 2005a). As revealed by Western blot, the ANKRD1/CARP protein content in the Purkinje-cell enriched samples was about 2-fold higher as compared to that in working myocytes (Torrado et al., 2006). The results indicate that ANKRD1/CARP may therefore play a previously unknown role in postnatal cardiac development of the specialized conduction system in ventricular myocardium.

Note 3: Like other Hairy-related transcriptional factors, Hey1 and Hey2 are controlled by a Notch signaling pathways and can act as transcriptional repressors. In the mouse, there is strong expression of Hey2 in the fetal ventricular myocardium that is gradually lost during postnatal development. Null mutants of Hey2, depending on genetic background, show either a marked cardiac hypertrophy or display various cardiac malformations (reviewed in: Brand, 2003).

Note 4: In the mouse, ablation of Sp3 results in a severe hypoplasia of the ventricular myocardium, which failed to form a compact layer. Among the genes studied, only ankrd1 showed a deregulated expression in Sp3-/-ventricular myocardium; the expression of Nkx2-5and gata-4 was not different between wild type and Sp3-/- hearts (van Loo et al., 2007). 
It is well accepted that loading conditions differ drastically between different chambers of fetal and postnatal heart. Therefore, chamber-dependent expression of ANKRD1/CARP from late fetal stages through adulthood can be influenced by different types of biomechanical stress in atrial versus ventricular and left versus right myocardium.

\section{Modulations of ANKRD1 expression in diseased myo- cardium: the result of myocardial damage and dysfunc- tion regardless of the cause}

Initial evidence for the possible involvement of the ankrd1gene in cardiac pathology was obtained using muscle LIM-only protein (MLP)-deficient mice which had developed a severe dilative enlargement of the heart (resembling human dilated cardiomyopathy - DCM) followed by ventricular hypertrophy and HF after birth. Significant up-regulation of the ankrd1 gene was observed in both dilated and hypertrophied ventricles (Arber et al., 1997; Baumeister et al., 1997). Later, it has been demonstrated that DCM-like phenotypes resulted from very different initial insults are also associated with a strong ankrd1 up-regulation in the LV myocardium (Table 2 and references wherein). Further, ankrd1 mRNA and protein levels were significantly increased in LV myocardium samples obtained from patients with end-stage $\mathrm{HF}$ due to idiopathic non-ischemic DCM (Zolk et al., 2003; Nagueh et al., 2004; Torrado et al., 2005b). Cardiac-tissue fractionation experiments followed by Western blot identification suggested that ANKRD1/CARP is mainly localized in nuclei and weakly expressed in the cytoplasm of human failing and non-failing myocardium (Zolk et al., 2002). However, these findings were not confirmed by immunohistochemical analysis of normal and diseased human myocardium by which ANKRD1/CARP-specific immunoreactivity was localized in the cytoplasm, being barely detectable in the nucleus (Ishiguro et al., 2002; Nagueh et al., 2004).

At first glance, these results point to ankrd1 up-regulation as the end-stage DCM-specific feature which might be responsible for dysregulation of gene expression in failing DCM-myocardium (Zolk et al., 2002; Baudet, 2003; Zolk et al., 2003). However, ankrd1 expression has been demonstrated to be up-regulated in the LV at various different pathophysiological states, namely, in animals models of cardiac hypertrophy (Kuo et al., 1999; Aihara et al., 2000; Johnatty et al., 2000), non-lethal cardiac ischemia (Depre et al., 2001), genetically induced (Gotthardt et al., 2003) or cardiotoxic CM (Torrado et al., 2004; Torrado et al., 2006), and in the heart of animals with streptozotocin-induced diabetes (Lehti et al., 2007) as well as, in patients with ischemic CM (Zolk et al., 2002) or ventricular septal defects (Zhang et al., 2006). Certainly, induction of ankrd1 overexpression in LV myocardium is a heart disease-relevant phenomenon, but this gene augmented expression is associated with a wide range of different cardiac disease states.

Although this field of study is extensive, several gaps in our knowledge on ankrd1 expression patterns at HF still exist. Given known limitations for myocardial biopsies in rodent models, as well as in patients, these studies almost uniformly used LVderived specimens, although the gene is expressed in all cardiac chambers. To overcome such limitations, we examined the fingerprint of ankrd1 expression throughout the heart in a large-animal model that is most relevant to human heart, i.e., a pig model of HF. Neonatal piglets exposed to different doses of cardiotoxic antibiotic, Doxorubicin (Dox), develop either systolic or diastolic HF (Torrado et al., 2004; Torrado et al., 2005b; Torrado et al., 2006). At diastolic HF, normal atrial versusventricular ankrd1expression pattern (Torrado et al., 2004) is oppositely regulated (at mRNA and protein levels), and is augmented about 2-fold in each ventricle, but equally reduced in both atria as compared to controls. Ankrd1 down-regulation in atria is a differential sign of diastolic HF, since systolic HF results in ankrd1 up-regulation in both atria and ventricles (Torrado et al., 2006). A marked ankrd1 up-regulation (at mRNA and protein levels) was also observed in atria in a porcine model of pacing-induced atrial fibrillation, with slightly increased nuclear localization of ANKRD1/CARP protein in the fibrillating atria as compared to sham controls (Chen et al., 2007). In human HF due to DCM, no difference in ANKRD1/CARP proteins levels was observed between right atria from failing and non-failing donor hearts (Zolk et al., 2002).

Taken together, the data suggest that: (1) distinct ankrd1 regulatory programs may be operative in diseased ventricular versus atrial myocardium, (2) the vast majority of HF phenotypes is associated with ankrd1 up-regulation in diseased ventricular myocardium, and (2) up-regulation of ankrd1 expression at various different forms of HF is unlikely to be a common molecular key that unlocks the pathological process, but rather appears to be a case of non disease-specific transcriptional adaptation of the heart to myocardial stress and injury.

Correlation between elevated levels of ANKRD1/CARP in the LV myocardium and various end-stage HF-phenotypes has tended to be interpreted as an indicator of an unfavorable clinical outcome (Zolk etal., 2002; Baudet, 2003; Zolk etal., 2003). However, it was unclear whether ventricular ankrd1 overexpression is causally related to the development of HF malignant phenotypes or if it is one of the adaptive reactions that antagonize the progressive loss of cardiac performance efficiency.

\section{ANKRD1 as a negative regulator of cardiac gene ex- pression: in vitro versus in vivo paradigm}

Few studies have addressed this question explicitly at the cellular level in vitro. As mentioned above, ANKRD1 has been identified as a nuclear cardiac ankyrin repeat protein (abbreviated as CARP) by two-hybrid screening of a neonatal rat ventricular cDNA library, using the transcriptional YB-1 factor as bait. Coimmunoprecipitation and GST-ANKRD1/CARP pulldown studies further confirmed that ANKRD1/CARP does form a physical complex with YB-1 in cardiomyocytes. Results of in vitro cell cotransfection assays revealed that ANKRD1/CARP prevents the activation of the promoter of the myosin light chain 2 ventricular ( $\mathrm{m} / \mathrm{c} 2 \mathrm{~V}$ ) gene probably by binding with and inhibiting activity of YB1 (Zou et al., 1997).

Evidence consistent with the definition of ANKRD1/CARP as a possible negative regulator of cardiac gene expression (Zou et al., 1997) is also provided by Jeyaseelan (Jeyaseelan et al., 1997), who show that forced ankrd1 expression in cultured neonatal cardiomyocytes inhibits activity of atrial natriuretic factor (ant) and troponin C (tnnc) gene promoters. Later, however, these results have ironically been cited by other authors who listed cardiac $\alpha$-actin, skeletal $\alpha$-actin (Aihara etal., 2000) and $\beta$-myosin 
heavy chain (Zolk et al., 2003), along with m/c2v and tnnc, as target genes which expression could be negatively regulated by ANKRD1/CARP. Using in vitro engineered heart tissue, it has been demonstrated that adenoviral-mediated ankrd1 overexpression in neonatal rat cardiomyocytes inhibits their contractile responsiveness to elevated concentrations of exogenously added catecholamines (Zolk et al., 2003). The relevance of these findings to a proposed ANKRD1/CARP inhibition of cardiac gene expression remains uncertain, because the transcriptional changes of cardiomyocytes in response to ankrd1 forced expression have not been reported.

The ANKRD1/CARP factor has often been referred to as a negative regulator of $m / c 2 v$ expression during cardiac development. It has even been proposed that one role of ANKRD1/CARP is to downregulate $m / c 2 v$ in atrium domains, thereby limiting $m / c 2 v$ expression to the ventricular myocardium (Krieg, 2001). Such interpretations of the results obtained from in vitromanipulated neonatal cardiomyocytes have not been yet experimentally confirmed in vivo. In this sense, the reduced expression of both ankrd1 (Zou et al., 1997) and m/c2v (Lyons et al., 1995) in a Nkx2.5-deficient background does not correlate well with the demonstration that ANKRD1/CARP inhibits the m/c2v reporter gene activity in vitro. Moreover, $m / c 2 v$ was not identified as the gene downregulated in the LV myocardium of MLP-deficient mice (Gao et al., 2006), and no decreased levels of MLC2v and TNNC were detected in $\mathrm{MLP}^{-/-}$hearts characterized by very high levels of ankrd1expression as compared to controls (Arber et al., 1997). In patients, end-stage DCM is associated with a marked activation of the ankrd1 (see Table 2) and selective upregulation (not inhibition) of the m/c2vgene in failing as compared to non-failing LV myocardium (Haase et al., 2002). In addition, our comparative analysis of left and right ventricular biopsies from newborn piglets characterized by a 10-fold difference in the ankrd1 transcript and protein presentation did not reveal any differences in either MLC2v transcript and protein content between the two ventricular chambers (Torrado et al., 2004).

ANKRD1/CARP negative regulation of the anf-promoter observed in ankrd1-transfected neonatal cardiomyocytes in vitro (Jeyaseelan et al., 1997) is not in line with results on temporal and regional-specific expression of the ankrd1 and anfgene in vivo. Anf is initially expressed in both the atrial and ventricular domains with higher levels of expression in the LV than in the RV. Expression of the anfgene becomes atrial-restricted later during cardiac development, at about the time of birth in mammals (Habets et al., 2003; Small and Krieg, 2004). As mentioned above, in the early postnatal mammalian heart ankrd1 is expressed in atria at much higher levels than in ventricles. Therefore, cardiac ankrd1 hyper-production in vivo is not necessarily associated with inhibition of anfexpression.

Although no evidence has yet been provided, induction of ankrd1 expression has been claimed to inhibit cardiac protein synthesis and cell enlargement, suggesting therefore that in vivo ANKRD1/CARP might have inhibitory effects on ventricular hypertrophy (Aihara et al., 2000; Han et al., 2004). These works, however, offer no direct evidence for such an ANKRD1/CARP anti-hypertrophic mechanism.

How is it that ANKRD1/CARP inhibits m/c2v-and anf-gene activities in in vitro cultured cardiomyocytes, but not in the myocardium itself in vivo? This can be attributable to differences between the results obtained in in vitro versus in vivo models. In vitro binding assays and cell-culture transfections with plasmid constructs not always correspond to in vivoassays. Discordance between in vitro cell-culture studies and animal models in vivo may also be explained by the presence of trans-acting factors in the hearts absent in the cardiomyocyte cultures used for transfection analyses. Formally, in vitro established associations should be mechanistically confirmed in animal models to demonstrate their biological relevance. In this regard, the proposed role for ANKRD1/CARP as a negative regulator of $m / c 2 v$, tnnc and anf gene expression has not been validated in animal models of cardiac hypertrophy (van den Bosch et al., 2006) associated with significant ankrd1 up-regulation in the LV myocardium of experimental animals as compared to controls. In other experimental settings (Arber et al., 1997; Torrado et al., 2004; Torrado et al., 2006), no appreciable differences in the level of expression and content of contractile proteins were observed between the cardiac samples characterized by quite different levels of ankrd1 expression. More broadly, it becomes particularly difficult to interpret, in this light, the significance of in vivo ANKRD1/CARP over-production in failing myocardium (see section above) from the standpoint of ANKRD1/CARP negative regulation of cardiac gene expression (Zolk et al., 2002), simply because in many HF phenotypes a remarkably significant ankrd1 up-regulation is associated with re-activation (not inhibition) of the anf gene expression (Nanni et al., 2006; Nishikimi et al., 2006) in the ventricular myocardium.

In conclusion, the analysis of available data still fails to define ANKRD1/CARP as a negative regulator of cardiac gene expression in vivo, but rather indicates that its augmented expression may represent a universal adaptive response of the myocardium to numerous different hemodynamic, biomechanical, genetics or cardio-toxic stimuli.

\section{ANKRD1 as a stress-inducible cardiac factor: from expression patterns to functional interpretation}

As discussed above, many studies have implicated ankrd1 over-production in LV hypertrophy at heart development, growth and disease, suggesting that its up-regulation is a common feature of the adaptive response of ventricular myocardium to pressure overloads. It should be noted, in this sense, that cardiac hypertrophy represents a general response to cardiac stress overloads, and that hypertrophic growth per se does not trigger cardiac dysfunction (Perrino et al., 2006). In fact, ankrd1 was found to be up-regulated at both physiological (Aihara etal., 2000; Torrado et al., 2004) and experimental pressure-induced LV hypertrophy not accompanied by altered systolic function (Weinberg et al., 2003).

It was reported that an adenoviral ankrd1-expressing vector implanted subcutaneously in rats promotes neovascularization and increased blood perfusion (Shi et al., 2005), which raises the intriguing question of whether or not ANKRD1/CARP might promote angiogenesis (Boengler et al., 2003) in response to myocardial ischemia. Of note, transient ischemia/perfusion without irreversible cardiac damage is associated with a rapid ankrd1 upregulation even when neither hypertrophy nor apoptosis are detected in stunned LV myocardium (Depre et al., 2001).

In mice, lacking ankrd1, no structural, molecular and functional 


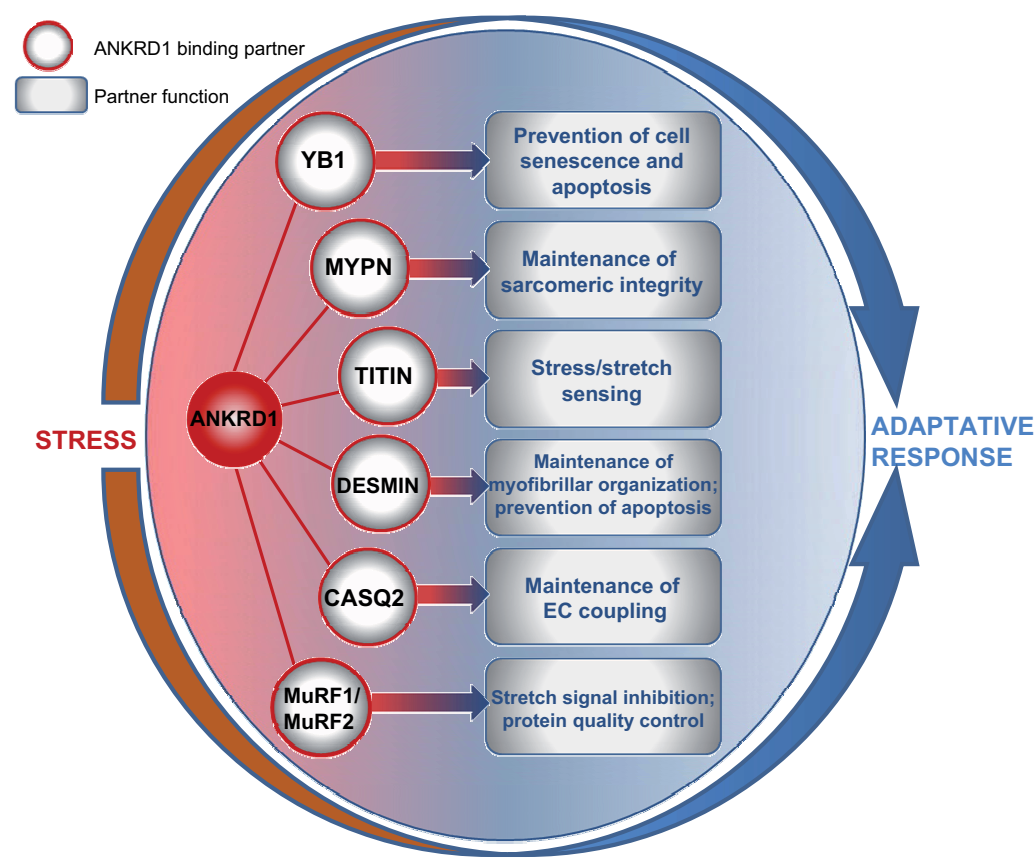

Fig. 3. ANKRD1/CARP as an integral part of cardiomyocyte stress-response circuits. The direct interactions of ANKRD1/CARP with its binding partners suggest how this factor may be involved in stress response pathways. YB-1, Y-box transcriptional factor 1; MYPN, myopalladin; CASQ2, cardiac calsequestrin. MuRF1/ MuRF2, muscle-specific RING finger 1 and 2 ubiquitin ligases; $E C$, excitationcontraction.

alterations were detected in skeletal muscles. This outcome seems not to be ascribed to a redundancy within this protein family, because ankrd1 removal is not associated with compensatory upregulation of the two remaining MARPs in muscle tissues (Barash et al., 2007). Given that ankrd1 is involved in muscle cell response to oxidative stress (Avivi et al., 2006), we suggest that the phenotype of the ankrd1 knockout might become apparent when the mice are exposed to hypoxic conditions.

Forced ankrd1 expression in rat embryonic $\mathrm{H} 9 \mathrm{c} 2$ cardiomyoblasts increased their resistance to hypoxia-induced apoptosis (Han et al., 2005). These observations are consistent with the hypothesis that ANKRD1/CARP plays a role in the protection of human microvascular endothelial cells (MVECs) from stress-induced apoptosis. In fact, ankrd1 transduction of Dox-treated MVECs increased cell survival that correlated with a

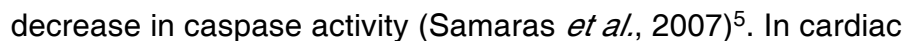
muscle, the inhibition of gene expression by Dox has been linked to reduced activity of $N k \times 2.5$, which protects heart from Dox through controlling transcriptional homeostasis of its cardio-restricted target genes, ankrd1 and anf (Toko et al., 2002). In support of this model is the observation that suppression of ankrd1 expression in adult rat ventricular cardiomyocytes results in myofibrillar disarray similar to that of Dox-treated cells (Chen et al., 2006). In addition, rapid and significant ankrd1 induction was observed after the passive stretch of beating fetal rat cardiomyocytes in vitro, indicating that the gene might be involved in the adaptive response of the myocardium to sarcomeric stretch-induced stress (Miller et al., 2003).

As mentioned above, ANKRD1/CARP can interacts with other proteins with a variety of functions related to prevention of premature cell senescence and apoptosis (YB-1), management of sarcomeric integrity (myopalladin) and myofibril orientation (desmin), biomechanical stress sensing (titin), calcium handling (CASQ2), and control of protein quality (MuRF1/MuRF2) (Fig. 3). Consequently, it is crucial for our further understanding of the functions of ANKRD1/CARP to elucidate these interactions and the effects that ANKRD1/CARP has on each of these molecules. The recent report found that ANKRD1/CARP is a natural caspase- 3 substrate, carrying at least one putative caspase-3 cleavage site at its $\mathrm{N}$ terminus (Ju et al., 2007). This cleavage site is located to one of the two titin-binding sequences identified in ANKRD1/CARP (see Fig. 1). Although this question has not been addressed in vivo, this finding suggests that: (1) ANKRD1/CARP can be one of apoptotic caspase-3 targets in cardiac muscle and (2) caspase-3-mediated cleavage of ANKRD1/CARP may affect its interaction with titin and, probably, with myopalladin.

The recent crop of results from ankrd1 expression association studies might seem like a sudden development. However, this blooming follows a relatively long period during which the primary concepts were developed and assembled. Insights into the function of ANKRD1/CARP originated from early studies on its inhibitory activity in functional promoter-reporter assays in vitro. Later, the interest has been focused on ankrd1 regulation at various stress conditions in vivo, including hemodynamic overload, cardiac hypertrophy and ischemia. A close examination of the findings strongly suggests that stress-induced activation of the ankrd1 gene is not only associated with a significant myocardial remodeling, but also involved in different signaling pathways that optimize response of cardiomyocytes to stress.

\section{Prospects}

Overexpression of ANKRD1/CARP in myocardium in vivo suggests that this factor may significantly contribute to physiological and pathological heart remodeling. In the last few years, there has been certain progress in understanding the physiological and pathological roles of ANKRD1/CARP in the heart. It is surprising, however, that most investigations have focused almost exclusively on the induction of ankrd1 expression in in vitro cultured primary cardiomyocytes or non-relevant cell lines. Thus, ANKRD1/ CARP-mediated pathways in cardiomyocytes in in vivo settings remain elusive. After a relatively long stagnation, we now need to probe in vivo, using target downregulation assays, if ankrd1 overexpression reflects this intrinsic role as a cardiac adaptive stress-response reaction. It is also hoped that the biological importance of ANKRD1/CARP will be revealed by the generation of transgenic animals exhibiting ANKRD1/CARP overexpression in the heart. Although overexpression models produce non- 
physiological levels of transcript and protein in the target tissue, they can still provide valuable insights into normal gene function in vivo. A modification of the transgenic approach to block the action of a target ANKRD1/CARP protein through the use of transgenes encoding dominant negative ANKRD1/CARP protein variants or using transgenic RNA interference approaches can provide useful information in cases where a total ankrd1 gene knockout results in subtle or no alterations.

\section{Acknowledgments}

This work was supported by a Grant (SAF2004-01462) from Spanish Ministry of Education and Science and partially by a Grant (PGIDITO4BTF161001PR) from Autonomic Government of Galicia.

\section{References}

AIHARA, Y., KURABAYASHI, M., ARAI, M., KEDES, L. and NAGAI, R. (1999). Molecular cloning of rabbit CARP cDNA and its regulated expression in adriamycin-cardiomyopathy. Biochim Biophys Acta 1447: 318-324.

AIHARA, Y., KURABAYASHI, M., SAITO, Y., OHYAMA, Y., TANAKA, T., TAKEDA, S., TOMARU, K., SEKIGUCHI, K., ARAI, M., NAKAMURA, T. and NAGAI, R. (2000). Cardiac ankyrin repeat protein is a novel marker of cardiac hypertrophy: role of M-CAT element within the promoter. Hypertension 36: 48-53.

AKAZAWA, H. and KOMURO, I. (2003a). Roles of cardiac transcription factors in cardiac hypertrophy. Circ Res 92: 1079-1088.

AKAZAWA, H. and KOMURO, I. (2003b). Too much Csx/Nkx2-5 is as bad as too little? J Mol Cell Cardio/35: 227-229.

ARBER, S., HUNTER, J.J., ROSS, J., JR., HONGO, M., SANSIG, G., BORG, J., PERRIARD, J.C., CHIEN, K.R. and CARONI, P. (1997). MLP-deficient mice exhibit a disruption of cardiac cytoarchitectural organization, dilated cardiomyopathy, and heart failure. Ce//88: 393-403.

AVIVI, A., BRODSKY, L., NEVO, E. and BAND, M.R. (2006). Differential expression profiling of the blind subterranean mole rat Spalax ehrenbergi superspecies: bioprospecting for hypoxia tolerance. Physiol Genomics 27: 54-64.

BALZA, R.O., JR. and MISRA, R.P. (2006). Role of the serum response factor in regulating contractile apparatus gene expression and sarcomeric integrity in cardiomyocytes. J Biol Chem 281: 6498-6510.

BANG, M.L., MUDRY, R.E., MCELHINNY, A.S., TROMBITAS, K., GEACH, A.J., YAMASAKI, R., SORIMACHI, H., GRANZIER, H., GREGORIO, C.C. and LABEIT, S. (2001). Myopalladin, a novel 145-kilodalton sarcomeric protein with multiple roles in Z-disc and I-band protein assemblies. J Cel/ Bio/153: 413-427.

BARASH, I.A., BANG, M.L., MATHEW, L., GREASER, M.L., CHEN, J. and LIEBER, R.L. (2007). Structural and regulatory roles of muscle ankyrin repeat protein family in skeletal muscle. Am J Physiol Cell Physio/293: C218-227.

BAUDET, S. (2003). Another activity for the cardiac biologist: CARP fishing. Cardiovasc Res 59: 529-531.

BAUMEISTER, A., ARBER, S. and CARONI, P. (1997). Accumulation of muscle ankyrin repeat protein transcript reveals local activation of primary myotube endcompartments during muscle morphogenesis. J Cel/ Bio/139: 1231-1242.

BOENGLER, K., PIPP, F., FERNANDEZ, B., ZIEGELHOEFFER, T., SCHAPER, W. and DEINDL, E. (2003). Arteriogenesis is associated with an induction of the cardiac ankyrin repeat protein (carp). Cardiovasc Res 59: 573-581.

BRAND, T. (2003). Heart development: molecular insights into cardiac specification and early morphogenesis. Dev Bio/258: 1-19.

BREWER, A. and PIZZEY, J. (2006). GATA factors in vertebrate heart development and disease. Expert Rev Mol Med8: 1-20.

BRUNEAU, B.G., NEMER, G., SCHMITT, J.P., CHARRON, F., ROBITAILLE, L., CARON, S., CONNER, D.A., GESSLER, M., NEMER, M., SEIDMAN, C.E. and SEIDMAN, J.G. (2001). A murine model of Holt-Oram syndrome defines roles of the T-box transcription factor Tbx5 in cardiogenesis and disease. Cel/106: 709-721.

CHEN, B., LIM, C., GUO, X. and SAWYER, D.B. (2006). Role of cardiac ankyrin repeat protein in doxorubicin induced sarcomeric disarray. Faseb J20: A1288.

CHEN, C.L., LIN, J.L., LAI, L.P., PAN, C.H., HUANG, S.K. and LIN, C.S. (2007).
Altered expression of FHL1, CARP, TSC-22 and P311 provide insights into complex transcriptional regulation in pacing-induced atrial fibrillation. Biochim Biophys Acta 1772: 317-329.

CHU, W., BURNS, D.K., SWERLICK, R.A. and PRESKY, D.H. (1995). Identification and characterization of a novel cytokine-inducible nuclear protein from human endothelial cells. J Biol Chem 270: 10236-10245.

CINQUETTI, R., BADI, I., CAMPIONE, M., BORTOLETTO, E., CHIESA, G., PAROLINI, C., CAMESASCA, C., RUSSO, A., TARAMELLI, R. and ACQUATI, F. (2008). Transcriptional deregulation and a missense mutation define ANKRD1 as a candidate gene for total anomalous pulmonary venous return. Hum Mutat 29: 468-474.

DEPRE, C., TOMLINSON, J.E., KUDEJ, R.K., GAUSSIN, V., THOMPSON, E., KIM, S.J., VATNER, D.E., TOPPER, J.N. and VATNER, S.F. (2001). Gene program for cardiac cell survival induced by transient ischemia in conscious pigs. Proc Nat/ Acad Sci USA 98: 9336-9341.

FISCHER, A., KLATTIG, J., KNEITZ, B., DIEZ, H., MAIER, M., HOLTMANN, B., ENGLERT, C. and GESSLER, M. (2005). Hey basic helix-loop-helix transcription factors are repressors of GATA4 and GATA6 and restrict expression of the GATA target gene ANF in fetal hearts. Mol Cel/ Bio/25: 8960-8970.

FRANCO, D. and CAMPIONE, M. (2003). The role of Pitx2 during cardiac development. Linking left-right signaling and congenital heart diseases. Trends Cardiovasc Med 13: 157-163.

GAO, Z., XU, H., DISILVESTRE, D., HALPERIN, V.L., TUNIN, R., TIAN, Y., YU, W., WINSLOW, R.L. and TOMASELLI, G.F. (2006). Transcriptomic profiling of the canine tachycardia-induced heart failure model: global comparison to human and murine heart failure. J Mol Cell Cardio/40: 76-86.

GAUSSIN, V., TOMLINSON, J.E., DEPRE, C., ENGELHARDT, S., ANTOS, C.L., TAKAGI, G., HEIN, L., TOPPER, J.N., LIGGETT, S.B., OLSON, E.N., LOHSE, M.J., VATNER, S.F. and VATNER, D.E. (2003). Common genomic response in different mouse models of beta-adrenergic-induced cardiomyopathy. Circulation 108: 2926-2933.

GESSLER, M., KNOBELOCH, K.P., HELISCH, A., AMANN, K., SCHUMACHER, N., ROHDE, E., FISCHER, A. and LEIMEISTER, C. (2002). Mouse gridlock: no aortic coarctation or deficiency, but fatal cardiac defects in Hey2 -/- mice. Curr Biol12: 1601-1604

GOTTHARDT, M., HAMMER, R.E., HUBNER, N., MONTI, J., WITT, C.C., MCNABB, M., RICHARDSON, J.A., GRANZIER, H., LABEIT, S. and HERZ, J. (2003). Conditional expression of mutant $\mathrm{M}$-line titins results in cardiomyopathy with altered sarcomere structure. J Biol Chem 278: 6059-6065.

GRANZIER, H.L. and LABEIT, S. (2004). The giant protein titin: a major player in myocardial mechanics, signaling, and disease. Circ Res 94: 284-295.

HAASE, D., LEHMANN, M.H., KORNER, M.M., KORFER, R., SIGUSCH, H.H. and FIGULLA, H.R. (2002). Identification and validation of selective upregulation of ventricular myosin light chain type 2 mRNA in idiopathic dilated cardiomyopathy. Eur J Heart Fail 4: 23-31.

HABETS, P.E., MOORMAN, A.F. and CHRISTOFFELS, V.M. (2003). Regulatory modules in the developing heart. Cardiovasc Res 58: 246-263.

HAN, H.C., AUSTIN, K.J., NATHANIELSZ, P.W., FORD, S.P., NIJLAND, M.J. and HANSEN, T.R. (2004). Maternal nutrient restriction alters gene expression in the ovine fetal heart. J Physio/558: 111-121

HAN, X.J., CHAE, J.K., LEE, M.J., YOU, K.R., LEE, B.H. and KIM, D.G. (2005). Involvement of GADD153 and cardiac ankyrin repeat protein in hypoxiainduced apoptosis of $\mathrm{H} 9 \mathrm{c} 2$ cells. J Biol Chem 280: 23122-23129.

HAYASHI, C., ONO, Y., DOI, N., KITAMURA, F., TAGAMI, M., MINEKI, R., ARAI, T., TAGUCHI, H., YANAGIDA, M., HIRNER, S., LABEIT, D., LABEIT, S. and SORIMACHI, H. (2008). Multiple molecular interactions implicate connectin/ titin N2A region as a modulating scaffold for p94/calpain 3 activity in skeletal muscle. J Biol Chem 283: 14801-14814.

HEIKINHEIMO, M., SCANDRETT, J.M. and WILSON, D.B. (1994). Localization of transcription factor GATA-4 to regions of the mouse embryo involved in cardiac development. Dev Bio/164: 361-373.

HIROI, Y., KUDOH, S., MONZEN, K., IKEDA, Y., YAZAKI, Y., NAGAI, R. and KOMURO, I. (2001). Tbx5 associates with Nkx2-5 and synergistically promotes cardiomyocyte differentiation. Nat Genet 28: 276-280.

HOSHIJIMA, M. and CHIEN, K.R. (2002). Mixed signals in heart failure: cancer rules. J Clin Invest 109: 849-855. 
IHARA, Y., SUZUKI, Y.J., KITTA, K., JONES, L.R. and IKEDA, T. (2002). Modulation of gene expression in transgenic mouse hearts overexpressing calsequestrin. Cell Calcium 32: 21-29.

IKEDA, K., EMOTO, N., MATSUO, M. and YOKOYAMA, M. (2003). Molecular identification and characterization of a novel nuclear protein whose expression is up-regulated in insulin-resistant animals. J Biol Chem 278: 3514-3520.

ISHIGURO, N., BABA, T., ISHIDA, T., TAKEUCHI, K., OSAKI, M., ARAKI, N., OKADA, E., TAKAHASHI, S., SAITO, M., WATANABE, M., NAKADA, C., TSUKAMOTO, Y., SATO, K., ITO, K., FUKAYAMA, M., MORI, S., ITO, H. and MORIYAMA, M. (2002). Carp, a cardiac ankyrin-repeated protein, and its new homologue, Arpp, are differentially expressed in heart, skeletal muscle, and rhabdomyosarcomas. Am J Pathol 160: 1767-1778.

JEYASEELAN, R., POIZAT, C., BAKER, R.K., ABDISHOO, S., ISTERABADI, L.B., LYONS, G.E. and KEDES, L. (1997). A novel cardiac-restricted target for doxorubicin. CARP, a nuclear modulator of gene expression in cardiac progenitor cells and cardiomyocytes. J Biol Chem 272: 22800-22808.

JOHNATTY, S.E., DYCK, J.R., MICHAEL, L.H., OLSON, E.N. and ABDELLATIF, M. (2000). Identification of genes regulated during mechanical load-induced cardiac hypertrophy. J Mol Cell Cardio/32: 805-815.

JU, W., VALENCIA, C.A., PANG, H., KE, Y., GAO, W., DONG, B. and LIU, R. (2007). Proteome-wide identification of family member-specific natural substrate repertoire of caspases. Proc Nat/ Acad Sci USA 104: 14294-14299.

KATHIRIYA, I.S., KING, I.N., MURAKAMI, M., NAKAGAWA, M., ASTLE, J.M., GARDNER, K.A., GERARD, R.D., OLSON, E.N., SRIVASTAVA, D. and NAKAGAWA, O. (2004). Hairy-related transcription factors inhibit GATA-dependent cardiac gene expression through a signal-responsive mechanism. $J$ Biol Chem 279: 54937-54943.

KOMURO, I. and IZUMO, S. (1993). Csx: a murine homeobox-containing gene specifically expressed in the developing heart. Proc Natl Acad Sci USA 90: 8145-8149.

KRIEG, P.A. (2001). Heart development: Gene control. In Encyclopedia of Life Sciences. John Wiley \& Sons, Ltd, pp.http://www.els.net/ [doi: 10.1038/ npg.els.0000736].

KUO, H., CHEN, J., RUIZ-LOZANO, P., ZOU, Y., NEMER, M. and CHIEN, K.R. (1999). Control of segmental expression of the cardiac-restricted ankyrin repeat protein gene by distinct regulatory pathways in murine cardiogenesis. Development 126: 4223-4234.

LAUSTSEN, P.G., RUSSELL, S.J., CUI, L., ENTINGH-PEARSALL, A., HOLZENBERGER, M., LIAO, R. and KAHN, C.R. (2007). Essential role of insulin and insulin-like growth factor 1 receptor signaling in cardiac development and function. Mol Cel/ Biol27: 1649-1664.

LEHTI, T.M., SILVENNOINEN, M., KIVELA, R., KAINULAINEN, H. and KOMULAINEN, J. (2007). Effects of streptozotocin-induced diabetes and physical training on gene expression of titin-based stretch-sensing complexes in mouse striated muscle. Am J Physiol Endocrinol Metab 292: E533-542.

LEIMEISTER, C., EXTERNBRINK, A., KLAMT, B. and GESSLER, M. (1999). Hey genes: a novel subfamily of hairy- and Enhancer of split related genes specifically expressed during mouse embryogenesis. Mech Dev 85: 173-177.

LYONS, I., PARSONS, L.M., HARTLEY, L., LI, R., ANDREWS, J.E., ROBB, L. and HARVEY, R.P. (1995). Myogenic and morphogenetic defects in the heart tubes of murine embryos lacking the homeo box gene Nkx2-5. Genes Dev 9: 16541666.

MAEDA, T., SEPULVEDA, J., CHEN, H.H. and STEWART, A.F. (2002). Alpha(1)adrenergic activation of the cardiac ankyrin repeat protein gene in cardiac myocytes. Gene 297: 1-9.

MIANO, J.M., LONG, X. and FUJIWARA, K. (2007). Serum response factor: master regulator of the actin cytoskeleton and contractile apparatus. Am J Physio/ Cell Physio/292: C70-81

MIKHAILOV, A.T. and TORRADO, M. (2006). The cardiac ankyrin repeat domain 1 protein: do you know enough about its dimerization properties? JMuscle Res Cell Motil27: 203-204.

MILLER, M.K., BANG, M.L., WITT, C.C., LABEIT, D., TROMBITAS, C., WATANABE, K., GRANZIER, H., MCELHINNY, A.S., GREGORIO, C.C. and LABEIT, S. (2003). The muscle ankyrin repeat proteins: CARP, ankrd2/Arpp and DARP as a family of titin filament-based stress response molecules. J Mo/ Bio/333: 951964.

MILLER, M.K., GRANZIER, H., EHLER, E. and GREGORIO, C.C. (2004). The sensitive giant: the role of titin-based stretch sensing complexes in the heart Trends Cel/ Biol 14: 119-126.

MOSAVI, L.K., CAMMETT, T.J., DESROSIERS, D.C. and PENG, Z.Y. (2004). The ankyrin repeat as molecular architecture for protein recognition. Protein Sci13: 1435-1448.

NAGUEH, S.F., SHAH, G., WU, Y., TORRE-AMIONE, G., KING, N.M., LAHMERS, S., WITT, C.C., BECKER, K., LABEIT, S. and GRANZIER, H.L. (2004). Altered titin expression, myocardial stiffness, and left ventricular function in patients with dilated cardiomyopathy. Circulation 110: 155-162.

NAKAI, K. and HORTON, P. (1999). PSORT: a program for detecting sorting signals in proteins and predicting their subcellular localization. Trends Biochem Sci24: 34-36.

NANNI, L., ROMUALDI, C., MASERI, A. and LANFRANCHI, G. (2006). Differential gene expression profiling in genetic and multifactorial cardiovascular diseases. J Mol Cell Cardiol 41: 934-948.

NISHIKIMI, T., MAEDA, N. and MATSUOKA, H. (2006). The role of natriuretic peptides in cardioprotection. Cardiovasc Res 69: 318-328.

OLSON, E.N. (2004). A decade of discoveries in cardiac biology. Nat Med10: 467474.

OLSON, E.N. (2006). Gene regulatory networks in the evolution and development of the heart. Science 313: 1922-1927.

OLSON, E.N. and SCHNEIDER, M.D. (2003). Sizing up the heart: development redux in disease. Genes Dev 17: 1937-1956.

PERRINO, C., NAGA PRASAD, S.V., MAO, L., NOMA, T., YAN, Z., KIM, H.S., SMITHIES, O. and ROCKMAN, H.A. (2006). Intermittent pressure overload triggers hypertrophy-independent cardiac dysfunction and vascular rarefaction. $J$ Clin Invest 116: 1547-1560.

SAMARAS, S.E., SHI, Y. and DAVIDSON, J.M. (2006). CARP: fishing for novel mechanisms of neovascularization. J Investig Dermatol Symp Proc 11: 124131.

SAMARAS, S.E., SHI, Y. and DAVIDSON, J.M. (2007). Novel actions of cardiac ankyrin repeat protein. International Congress Series 1302: 53-64.

SCHWARTZ, R.J. and OLSON, E.N. (1999). Building the heart piece by piece: modularity of cis-elements regulating Nkx2-5 transcription. Development 126: 4187-4192.

SEHL, P.D., TAI, J.T., HILLAN, K.J., BROWN, L.A., GODDARD, A., YANG, R., JIN, H. and LOWE, D.G. (2000). Application of cDNA microarrays in determining molecular phenotype in cardiac growth, development, and response to injury. Circulation 101: 1990-1999.

SHI, Y., REITMAIER, B., REGENBOGEN, J., SLOWEY, R.M., OPALENIK, S.R., WOLF, E., GOPPELT, A. and DAVIDSON, J.M. (2005). CARP, a cardiac ankyrin repeat protein, is up-regulated during wound healing and induces angiogenesis in experimental granulation tissue. Am J Patho/166: 303-312.

SMALL, E.M. and KRIEG, P.A. (2004). Molecular regulation of cardiac chamberspecific gene expression. Trends Cardiovasc Med14: 13-18.

TAKIMOTO, E., MIZUNO, T., TERASAKI, F., SHIMOYAMA, M., HONDA, H., SHIOJIMA, I., HIROI, Y., OKA, T., HAYASHI, D., HIRAI, H., KUDOH, S., TOKO, H., KAWAMURA, K., NAGAI, R., YAZAKI, Y. and KOMURO, I. (2000). Upregulation of natriuretic peptides in the ventricle of $\mathrm{Csx} / \mathrm{Nkx} 2-5$ transgenic mice. Biochem Biophys Res Commun 270: 1074-1079.

TOKO, H., ZHU, W., TAKIMOTO, E., SHIOJIMA, I., HIROI, Y., ZOU, Y., OKA, T., AKAZAWA, H., MIZUKAMI, M., SAKAMOTO, M., TERASAKI, F., KITAURA, Y., TAKANO, H., NAGAI, T., NAGAI, R. and KOMURO, I. (2002). Csx/Nkx2-5 is required for homeostasis and survival of cardiac myocytes in the adult heart. $J$ Biol Chem 277: 24735-24743.

TORRADO, M., IGLESIAS, R. and MIKHAILOV, A.T. (2008). Detection of protein interactions based on GFP-fragment complementation by fluorescence microscopy and spectrofluorometry. Biotechniques 44: 70-74.

TORRADO, M., LOPEZ, E., CENTENO, A., CASTRO-BEIRAS, A. and MIKHAILOV, A.T. (2004). Left-right asymmetric ventricular expression of CARP in the piglet heart: regional response to experimental heart failure. Eur J Heart Fail6: 161172.

TORRADO, M., NESPEREIRA, B., BOUZAMAYOR, Y., CENTENO, A., LOPEZ, E. and MIKHAILOV, A.T. (2006). Differential atrial versus ventricular ANKRD1 gene expression is oppositely regulated at diastolic heart failure. FEBS Lett580: 4182-4187. 
TORRADO, M., NESPEREIRA, B., LOPEZ, E., CENTENO, A., CASTRO-BEIRAS, A. and MIKHAILOV, A.T. (2005a). ANKRD1 specifically binds CASQ2 in heart extracts and both proteins are co-enriched in piglet cardiac Purkinje cells. JMol Cell Cardio/38: 353-365.

TORRADO, M., NESPEREIRA, B. and MIKHAILOV, A.T. (2005b). Fetal cardiac control genes: implications for postnatal heart growth and heart disease. Trends Dev Biol1: 27-38.

VAN DEN BOSCH, B.J., LINDSEY, P.J., VAN DEN BURG, C.M., VAN DER VLIES, S.A., LIPS, D.J., VAN DER VUSSE, G.J., AYOUBI, T.A., DOEVENDANS, P.A. and SMEETS, H.J. (2006). Early and transient gene expression changes in pressure overload-induced cardiac hypertrophy in mice. Genomics 88: 480488.

VAN LOO, P.F., MAHTAB, E.A., WISSE, L.J., HOU, J., GROSVELD, F., SUSKE, G., PHILIPSEN, S. and GITTENBERGER-DE GROOT, A.C. (2007). Transcription factor Sp3 knockout mice display serious cardiac malformations. Mo/ Cell Bio/27: 8571-8582.

WEINBERG, E.O., MIROTSOU, M., GANNON, J., DZAU, V.J., LEE, R.T. and PRATT, R.E. (2003). Sex dependence and temporal dependence of the left ventricular genomic response to pressure overload. Physiol Genomics 12: 113127.

WITT, C.C., WITT, S.H., LERCHE, S., LABEIT, D., BACK, W. and LABEIT, S. (2008). Cooperative control of striated muscle mass and metabolism by MuRF1 and MuRF2. Embo J27: 350-360.

WITT, S.H., LABEIT, D., GRANZIER, H., LABEIT, S. and WITT, C.C. (2005).
Dimerization of the cardiac ankyrin protein CARP: implications for MARP titinbased signaling. J Muscle Res Cell Motil26: 401-408.

XIANG, F., SAKATA, Y., CUI, L., YOUNGBLOOD, J.M., NAKAGAMI, H., LIAO, J.K., LIAO, R. and CHIN, M.T. (2006). Transcription factor CHF1/Hey2 suppresses cardiac hypertrophy through an inhibitory interaction with GATA4. Am J Physiol Heart Circ Physio/290: H1997-2006.

YU, C.S., CHEN, Y.C., LU, C.H. and HWANG, J.K. (2006). Prediction of protein subcellular localization. Proteins 64: 643-651.

ZHANG, H., ZHOU, L., YANG, R., SHENG, Y., SUN, W., KONG, X. and CAO, K (2006). Identification of differentially expressed genes in human heart with ventricular septal defect using suppression subtractive hybridization. Biochem Biophys Res Commun 342: 135-144.

ZOLK, O., FROHME, M., MAURER, A., KLUXEN, F.W., HENTSCH, B., ZUBAKOV, D., HOHEISEL, J.D., ZUCKER, I.H., PEPE, S. and ESCHENHAGEN, T. (2002). Cardiac ankyrin repeat protein, a negative regulator of cardiac gene expression, is augmented in human heart failure. Biochem Biophys Res Commun 293: 1377-1382.

ZOLK, O., MARX, M., JACKEL, E., EL-ARMOUCHE, A. and ESCHENHAGEN, T. (2003). Beta-adrenergic stimulation induces cardiac ankyrin repeat protein expression: involvement of protein kinase $\mathrm{A}$ and calmodulin-dependent kinase. Cardiovasc Res 59: 563-572.

ZOU, Y., EVANS, S., CHEN, J., KUO, H.C., HARVEY, R.P. and CHIEN, K.R. (1997). CARP, a cardiac ankyrin repeat protein, is downstream in the Nkx2-5 homeobox gene pathway. Development 124: 793-804. 


\section{Further Related Reading, published previously in the Int. J. Dev. Biol.}

See our recent Special Issue Fertilization, in honor of David L. Garbers and edited by Paul M. Wassarman and Victor D. Vacquier at: http://www.ijdb.ehu.es/web/contents.php?vol=52\&issue=5-6

See our recent Special Issue Ear Development edited by Fernando Giraldez and Bernd Fritzsch at: http://www.ijdb.ehu.es/web/contents.php?vol=51\&issue=6-7

Expression and comparative genomics of two serum response factor genes in zebrafish Jody L. Davis, Xiaochun Long, Mary A. Georger, lan C. Scott, Adam Rich and Joseph M. Miano Int. J. Dev. Biol. (2008) 52: 389-396

In vivo forced expression of myocardin in ventricular myocardium transiently impairs systolic performance in early neonatal pig heart

Mario Torrado, Alberto Centeno, Eduardo López and Alexander T. Mikhailov

Int. J. Dev. Biol. (2008) 52: doi: 10.1387/ijdb.072366mt

Heart formation and left-right asymmetry in separated right and left embryos of a newt

Kazuhiro Takano, Yuzuru Ito, Shuichi Obata, Tsutomu Oinuma, Shinji Komazaki, Hiroaki Nakamura and Makoto Asashima

Int. J. Dev. Biol. (2007) 51: 265-272

Myoskeletin, a factor related to Myocardin, is expressed in somites and required for hypaxial muscle formation in Xenopus

Hui Zhao, Martha L. Rebbert and Igor B. Dawid

Int. J. Dev. Biol. (2007) 51: 315-320

Amphibian in vitro heart induction: a simple and reliable model for the study of vertebrate cardiac development.

Takashi Ariizumi, Masayoshi Kinoshita, Chika Yokota, Kazuhiro Takano, Keiichi Fukuda, Nobuo Moriyama, George M Malacinski and Makoto Asashima

Int. J. Dev. Biol. (2003) 47: 405-410

Efficient Cre-mediated deletion in cardiac progenitor cells conferred by a 3'UTRires-Cre allele of the homeobox gene Nkx2-5.

Edouard G Stanley, Christine Biben, Andrew Elefanty, Louise Barnett, Frank Koentgen, Lorraine Robb and Richard P Harvey

Int. J. Dev. Biol. (2002) 46: 431-439

Induction and patterning of the cardiac conduction system.

David J Pennisi, Stacey Rentschler, Robert G Gourdie, Glenn I Fishman and Takashi Mikawa

Int. J. Dev. Biol. (2002) 46: 765-775

Heat shock factor 2 is activated during mouse heart development.

M Eriksson, E Jokinen, L Sistonen and S Leppä

Int. J. Dev. Biol. (2000) 44: 471-477

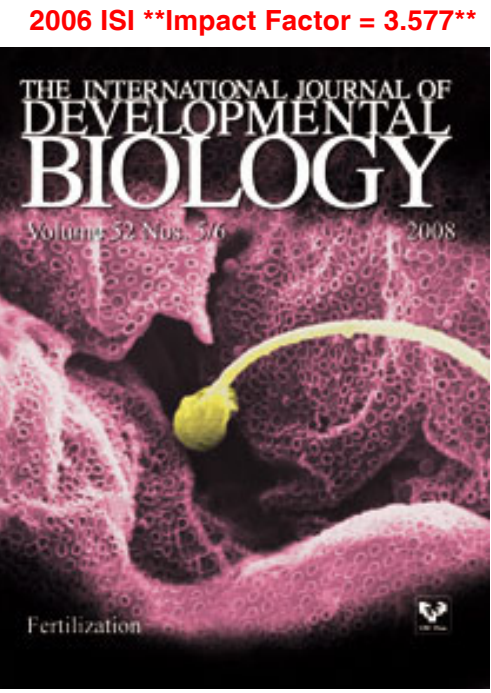

